\title{
Hypoargininemia exacerbates airway hyperresponsiveness in a mouse model of asthma
}

\author{
Roy H. E. Cloots ${ }^{1}$, Matthew E. Poynter ${ }^{3}$, Els Terwindt ${ }^{1}$, Wouter H. Lamers ${ }^{1,2}$ and S. Eleonore Köhler ${ }^{*}$
}

\begin{abstract}
Background: Asthma is a chronic respiratory condition, with airway hyperresponsiveness (AHR) and inflammation as hallmarks. The hypothesis that the substantially increased expression of arginase 1 in activated macrophages limits the availability of L-arginine for nitric oxide synthesis, and thus increases AHR in lungs of mice with experimentally induced allergic asthma was recently refuted by several studies. In the present study, we tested the hypothesis that, instead, a low circulating concentration of arginine aggravates AHR in the same murine asthma model. Female FVB F/A2 ${ }^{\text {tg/tg }}$ transgenic mice, which overexpress rat arginase 1 in their enterocytes, exhibit a $\sim 50 \%$ decrease of their plasma L-arginine concentration.

Methods: Adult female $F / A 2^{\text {tg/tg }}$ mice and their wild-type littermates (F/A2 $\left.2^{w t / w t}\right)$ were sensitized and challenged with ovalbumin (OVA/OVA). Lung function was assessed with the flexiVent ${ }^{\mathrm{TM}}$ system. Adaptive changes in the expression of arginine-metabolizing or -transporting enzymes, chemokines and cytokines, and lung histology were quantified with qPCR, ELISA, and immunohistochemistry, respectively.
\end{abstract}

Results: Reduction of circulating L-arginine concentration significantly increased AHR in OVA/OVA-treated mice and, to a lesser extent, even in PBS/OVA-treated mice. The pulmonary inflammatory response in OVA/OVA-treated $F / A 2^{\text {tg/tg }}$ and $F / A 2^{\text {Wt } / \text { t }}$ mice was comparable. OVA/OVA-treated F/A2 $2^{\text {tg/tg }}$ mice differed from similarly treated female mice, in which arginase 1 expression in lung macrophages was eliminated, by a complete absence of an adaptive increase in the expression of arginine-metabolizing or -transporting enzymes.

Conclusion: A reduction of the circulating L-arginine concentration rather than the macrophage-mediated increase of arginine catabolism worsens AHR.

Keywords: Arginine availability, Lung function, Transgenes, Pulmonary inflammation

\section{Background}

Allergic asthma is a chronic respiratory condition characterized by $\mathrm{T}_{\mathrm{H}}$ 2-predominant airway inflammation, increased mucus production, mucosal edema, airway hyperresponsiveness (AHR) and airway remodeling. Expression of the enzyme arginase is increased in asthmatic lungs. It has been suggested that increased arginase expression affects AHR by reducing L-arginine availability for nitric oxide synthases (NOS), thereby limiting the production of nitric oxide $(\mathrm{NO})[1,2]$.

\footnotetext{
* Correspondence: leo.koehler@maastrichtuniversity.nl

${ }^{1}$ Department of Anatomy \& Embryology and NUTRIM School of Nutrition and Translational Research in Metabolism, Maastricht University, P.O. Box 616, 6200MD, Maastricht, The Netherlands

Full list of author information is available at the end of the article
}

However, the relation appears to be complex. The contribution of the individual NOS enzymes to bronchodilation or AHR is difficult to determine since all three NOS isoforms are expressed in the lung and control each other's expression and activity [3]. Furthermore, L-arginine availability is not directly related to exhaled NO or inflammatory parameters in asthma, and is related to AHR only in severe asthma [4]. Intracellular L-arginine availability depends on its consumption by NO synthases and arginases, and its uptake into the cell through transporters, such as cationic (CATs) and heterodimeric amino-acid transporters (e.g. LAT1 and-2), and on recycling of L-citrulline (the other product of NOS activity) to L-arginine. CAT-mediated uptake of 
arginine is inhibited by other cationic amino acids, such as L-ornithine (a product of arginase activity) and lysine, but also by polycations, such as major basic protein (MBP; [5]), which is released by infiltrating eosinophils during the asthmatic response.

The effects of elimination of NOS isoforms [6-10] or arginase $1[11,12]$ on lung function and inflammation in mouse models of allergic asthma have been extensively investigated. In these animal models, NOS2 [9], arginase 1 $[11,13]$ and, to a lesser extent, arginase $2[14]$ are strongly upregulated. The more predominant arginase form, arginase 1 , is found in macrophages within the inflammatory infiltrates in the asthmatic lung [13]. The potential competition of arginase and NOS for their common substrate arginine explains the interest in the behavior of both enzymes. Although NO synthases have a $\sim 250$-fold higher affinity for L-arginine than arginases, arginases have a 1000-fold higher $V_{\max }$ than the NO synthases, which makes regional depletion of arginine [15] and uncoupling of NOS [16] a realistic possibility.

Although arginase 1 elimination in macrophages had major effects on the gene-expression profile of pulmonary macrophages, the effects on lung function were $a b-$ sent in both BALB/c and C57BL/6 mice $[12,17,18]$, or limited to the peripheral airways in male C57BL/6 mice [11]. We, therefore, hypothesized that macrophages were less important for the regulation of local arginine availability in the airways than anticipated and that, instead, the circulating concentration of arginine played the more important role in supplying arginine for NO synthesis and relaxation of airway smooth muscles. To test this hypothesis, we studied mice in which the circulating L-arginine concentration was decreased to $\sim 45 \%$ of control mice due to overexpression of arginase 1 in the enterocytes of their intestines [19] and sensitized and exposed them to ovalbumin to induce an asthmatic phenotype.

\section{Methods}

\section{Animals}

F/A2 transgenic mice on a FVB background, which overexpress rat arginase 1 in their enterocytes [19], were bred hemizygously $\left(F / A 2^{w t / t g}\right)$. We studied female homozygous $\left(F / A 2^{\operatorname{tg} / \mathrm{tg}}\right)$ mice and used their female wild-type $\left(F / A 2^{w t / w t}\right)$ littermates as controls. All mice were approximately 10 weeks at the start of the experiments. The study was reviewed and approved by the committee for animal care and use of Maastricht University (DEC2005-146).

\section{Antigen sensitization and challenge}

Mice were injected intraperitoneally on days 0 and 14 with $10 \mu \mathrm{g}$ ovalbumin (OVA), grade V (Sigma-Aldrich, Zwijndrecht, The Netherlands) in a total volume of
$100 \mu \mathrm{L}$ PBS, containing $1 \mathrm{mg} / \mathrm{mL}$ of $\mathrm{AlOH}_{3}$ (alum) as adjuvant (Imject Alum ${ }^{\circ}$, Thermo Scientific, Rockford, IL, USA). To ensure an adequate induction of gene expression in the sensitized and challenged mice, we performed a time-course study. Additional file 1: Figure S1 shows that daily exposure to $1 \%$ OVA for $30 \mathrm{~min}$ strongly increased $\operatorname{Arg1}$, Nos2, and Cd68 expression after 6 days of treatment. Mice were, therefore, exposed on days $21-27$ to daily aerosol challenges with $1 \%(w / v)$ OVA in PBS for $30 \mathrm{~min}$ in custom-made inhalation chambers. Lung function was assessed $12 \mathrm{~h}$ after the last challenge.

\section{Airway hyperresponsiveness}

The protocol was described previously [11]. In brief, female mice were injected intraperitoneally with $80 \mathrm{mg} / \mathrm{kg}$ sodium pentobarbital to induce anesthesia, followed by $40 \mathrm{mg} / \mathrm{kg}$ after $30 \mathrm{~min}$ for anesthesia maintenance. An 18-gauge blunt needle was inserted into the trachea and connected to a mechanical small-animal ventilator (flexiVent $^{\mathrm{m}}$, Scireq, Montreal, Canada). The mice were ventilated at 200 breaths/min with a delivered tidal volume of $0.25 \mathrm{~mL}$ against a positive end expiratory pressure (PEEP) of $3 \mathrm{~cm} \mathrm{H}_{2} \mathrm{O}$ applied by a water trap. Aerosolized methacholine (Sigma, Steinheim, Germany) challenges were performed by delivering successively 0 , 3.1, 12.5 and $50.0 \mathrm{mg} / \mathrm{mL}$ methacholine in PBS. Following each aerosol challenge, ventilation was interrupted every $10 \mathrm{~s}$ to allow for a 1-s passive expiration followed by a 2 -s broad-band $(1-19.6 \mathrm{~Hz})$ volume perturbation. The peak-to-peak excursion of the ventilator piston during delivery of these perturbations was $0.17 \mathrm{~mL}$, resulting in a delivery of $\sim 0.14 \mathrm{~mL}$ after correcting for gas compression in the ventilator cylinder and connecting tubing. Pressure and flow were recorded during application of the perturbations and used to calculate the input impedance $\left(Z_{\mathrm{rs}}\right)$ of the respiratory system. $Z_{\mathrm{rs}}$ was then fitted to the uniformly ventilated model of the lung with constant-phase tissue impedance $[20,21]$.

\section{Plasma collection and analysis}

On day 27, after completing the Flexivent analysis, blood was collected from the inferior caval vein in heparin-coated tubes, centrifuged for $3 \mathrm{~min}$ at $5000^{*} \mathrm{~g}$, snap frozen in liquid nitrogen and stored at $-80{ }^{\circ} \mathrm{C}$. Plasma OVA-specific IgE levels were determined by ELISA (Product \#: M036005, MD Biosciences, Zürich, Switzerland). For the determination of plasma amino acids, $50 \mu \mathrm{L}$ of plasma was added to $4 \mathrm{mg}$ sulfosalicylic acid, vortexed, snap-frozen in liquid nitrogen and stored at $-80{ }^{\circ} \mathrm{C}$ until use. Plasma amino acid concentrations were measured using a fully automated HPLC system [22]. 


\section{Tissue isolation}

Immediately following euthanasia, lungs were isolated. The left lung was filled with $4 \%$ formaldehyde (Klinipath, Deventer, the Netherlands) for $10 \mathrm{~min}$ at a pressure of $20 \mathrm{~cm} \mathrm{H}_{2} \mathrm{O}$ and submersed for $24 \mathrm{~h}$ in $4 \%$ formaldehyde at room temperature (RT) prior to paraffin embedding. The right lung was snap-frozen in liquid nitrogen and pulverized in a liquid-nitrogen-chilled mortar and pestle. Lung tissue powder was stored at $-80{ }^{\circ} \mathrm{C}$ until further use.

\section{Immunostaining}

Paraffin-embedded tissue was cut into $4 \mu \mathrm{m}$ sections and stained with haematoxylin \& eosin. For immunostaining, antigens were retrieved by heating the slides for $5 \mathrm{~min}$ in $10 \mathrm{mmol} / \mathrm{L}$ sodium citrate $(\mathrm{pH} 6)$ at $95{ }^{\circ} \mathrm{C}$ and cooling to room temperature (RT) in $30 \mathrm{~min}$ before blocking endogenous peroxidases with peroxidase block (DAKO, S2001, Enschede, the Netherlands) for $10 \mathrm{~min}$ at RT. This step was omitted if antibody binding was visualized with the alkaline phosphatase (AP) system. Sections were blocked with 10\% normal goat serum for $30 \mathrm{~min}$, followed by incubation with anti-arginase 1(Amsterdam Liver Center, AMS40.11.13), anti-myeloperoxidase (MPO; DAKO), or anti-murine major basic protein (mMBP; LeeLab, MT14.3.7, Mayo Clinic Scottsdale, AZ, USA) [23]. After washing, sections were incubated with a 1:200 diluted biotinylated rabbit anti-rat secondary antibody (DAKO) for $45 \mathrm{~min}$ at RT. Sections were washed, incubated with streptavidin/HRP (Vector) for $30 \mathrm{~min}$ at room temperature, and developed with 3,3'-diaminobenzidine (Sigma, Steinheim, Germany) for $10 \mathrm{~min}$. Sections stained for arginase 1 were incubated with an AP-labeled secondary antibody (DAKO) for 45 min, developed with NitroBlue-Tetrazolium and 5-Bromo-4-Chloro-3-Indolyl phosphate (Roche, Almere, The Netherlands) dissolved in $50 \mathrm{mmol} / \mathrm{L} \mathrm{MgSO}_{4}$, $100 \mathrm{mmol} / \mathrm{L}$ Tris. $\mathrm{HCl}(\mathrm{pH}$ 9.5) for $30 \mathrm{~min}$, and cover-slipped with an aqueous mounting medium (DAKO).

\section{Histopathology}

Whole-lung tissue sections stained with $H \& E$, or the MBP and MPO antisera were scored independently by two persons at 10X magnification. Scores were: $0:<5$ inflammatory cells per field; $1: 5-25$ inflammatory cells per field; 2: 25-50 inflammatory cells per field; $3:>50$ inflammatory cells per field.

\section{Milliplex assay}

Lung tissue powder was homogenized in PBS, $\mathrm{pH}$ 7.6, in the presence of a proteinase inhibitor cocktail (Roche, Complete). Cytokines (IL-4, IL-10, and IL-13) were quantified using a Luminex $^{\circ} \mathrm{xMAP}^{\circ}$ multiplex platform, combined with a customized Milliplex ${ }^{\text {ma }}$ mouse chemokine/cytokine panel (Merck, Amsterdam, the Netherlands).

\section{RNA isolation and quantification}

Lung tissue powder was homogenized in Tri reagent (Sigma) with the Mini Bead-Beater (Biospec products, Bartlesville, OK, USA). To remove genomic DNA, RNA was precipitated with $2 \mathrm{~mol} / \mathrm{L} \mathrm{LiCl}$ for at least $30 \mathrm{~min}$ at $-20{ }^{\circ} \mathrm{C}$. RNA integrity was checked by denaturing gel electrophoresis. RNA concentration was determined with a NanoDrop-ND-1000 spectrophotometer at $260 \mathrm{~nm}$ (Isogen Life Sciences, Wilmington, DE, USA). $400 \mathrm{ng}$ of total RNA was transcribed using the Roche first-strand synthesis kit (Roche). Quantitative PCR was performed in the Lightcycler 480 (Roche), using the Lightcycler $480^{\circ}$ SYBRgreen mastermix (Roche) and the following settings: denaturation $30 \mathrm{~s}$ at $95^{\circ} \mathrm{C}$; annealing $30 \mathrm{~s}$ at $60^{\circ} \mathrm{C}$; elongation $30 \mathrm{~s}$ at $72{ }^{\circ} \mathrm{C} ; 45$ cycles; and a final elongation step for $5 \mathrm{~min}$ at $72{ }^{\circ} \mathrm{C}$. If reverse transcriptase was omitted, no product was formed. Primary fluorescent data were exported and analyzed with the Lin-Reg Analysis program [24]. mRNA abundance was expressed relative to $18 \mathrm{~S}$ rRNA abundance. Primer sequences are given in Additional file 2: Table S1.

\section{Western blot}

Lung tissue powder was homogenized in RIPA buffer: $25 \mathrm{mmol} / \mathrm{L}$ Tris. $\mathrm{HCl}, \mathrm{pH}$ 7.6, $150 \mathrm{mmol} / \mathrm{L} \mathrm{NaCl}, 1 \%$ NP-40, 1\% Na-deoxycholate, $0.1 \%$ SDS, containing Complete $^{\circ}$ cocktail (Roche). Protein concentration was measured with the bicinchoninic-acid assay (Pierce, Rockford, IL, USA). $25 \mu$ g protein was separated on an SDS-polyacrylamide gel, transferred onto $0.45 \mu \mathrm{m}$ nitrocellulose membranes, using a wet transfer system (Biorad, Hercules, CA, USA), stained with Ponceau S to confirm equal loading of lanes, washed with TBS $(50 \mathrm{mmol} / \mathrm{L}$ Tris, $150 \mathrm{mmol} / \mathrm{L} \mathrm{NaCl}, \mathrm{pH}$ 7.6) and blocked with 5\% skimmed milk in TBS/ $0.5 \%$ Tween-2. Arginase 1 was visualized with rabbit anti-arginase 1 antibody (1:200), followed by an HRP-conjugated swine anti-rabbit secondary antibody (DAKO). The signal was developed using the Super Signal West Pico Substrate (Pierce) and quantified with the Fuji systems darkbox (Fuji Film Life Sciences, Tokyo, Japan).

\section{Statistical analyses}

Comparison of groups was performed using the Kruskal-Wallis test for PBS/OVA- versus OVA/OVA-treated, and $F / A 2^{w t / w t}$ versus $F / A 2^{\operatorname{tg} / t g}$ mice. Only when this nonparametric test indicated a difference between experimental groups, a multiple comparison of the groups was carried out. Values were considered 
statistically significant if $P<0.05$, and as indicating a trend if $P<0.1$.

The bivariate, two-tailed Spearman correlation coefficients between each of the lung-function parameters, mRNA and protein concentrations, histology scores and plasma amino-acid concentrations were determined after combining the data from the comparable PBS/OVA and OVA/OVA groups. In the Tables, $P$-values of the resulting correlation coefficients were color-coded, with red indicating $P<0.001$, orange $0.01>P>0.001$, and yellow $0.05>P>0.01$.

\section{Results}

Hypoargininemia does not affect the response to allergic asthma

Overexpression of arginase 1 in the enterocytes of the small intestine decreases plasma arginine concentration, in particular in female mice (Figs. 1 and 2). In male $F / A 2^{t g / t g}$ mice, plasma arginine concentration was $\sim 90 \mu \mathrm{mol} / \mathrm{mL}$ and in female $F / A 2^{\operatorname{tg} / \operatorname{tg}}$ mice $\sim 63$ $\mu \mathrm{mol} / \mathrm{mL}$, or $\sim 70 \%$ and $\sim 50 \%$ of their wild-type male and female littermates, respectively (Fig. 1). Because of their more pronounced hypoargininemia we confined our study to female mice. Treatment of female control $\left(F / A 2^{w t / w t}\right)$ and transgenic $\left(F / A 2^{t g / t g}\right)$ mice with the PBS/OVA or the OVA/OVA protocol did not affect plasma arginine concentration significantly (Fig. 2a). Since plasma concentrations of all other amino acids did not change between conditions or genotypes (Additional file 2: Table S2), arginine bioavailability indices such as $[\mathrm{Arg}] /([\mathrm{Orn}]+[\mathrm{Lys}])$ (competition for CAT transporters) and $[\mathrm{Arg}] /([\mathrm{Orn}]+[\mathrm{Cit}]$ ) (intracellular metabolism of arginine) declined correspondingly. Induction of experimental asthma increased arginase 1 expression in lungs dramatically (Fig. 2b), as observed previously [11-13]. We next investigated whether hypoargininemia was associated with adaptive changes in the expression of arginine-metabolizing enzymes or arginine transporters in the lung under allergically inflamed conditions. The pulmonary mRNA abundance of the arginine-metabolizing enzymes Arg1, Arg2, Nos2 (Fig. 2c-e), and the arginine transporters Slc7a1, Slc7a2 and Slc7a7 (Fig. 2f-h) did not differ significantly between $F / A 2^{t g / t g}$ and $F / A 2^{w t / w t}$ mice under control conditions (PBS/OVA protocol) All mRNAs increased in both $F / A 2^{w t / w t}$ and $F / A 2^{t g / t g}$ mice when exposed to the OVA/OVA protocol (Fig. 2), but the increase did not reach significance for $A r g 2$ and Slc7a2 in $F / A 2^{w t / w t}$ mice.

\section{Hypoargininemia exacerbates allergen-induced airway hyperresponsiveness}

To answer the question whether hypoargininemia has an effect on respiratory mechanics, we measured lung function in PBS/OVA- and OVA/OVA-treated $F / A 2^{\text {tg/tg }}$ and $F / A 2^{w t / w t}$ mice. Airway resistance $\left(\mathrm{R}_{\mathrm{N}}\right)$ in response to methacholine-challenges did not differ between PBS/ OVA and OVA/OVA-treated wild-type mice (Fig. 3a, b), but was significantly higher in $F / A 2^{\text {tg/tg }}$ mice undergoing OVA/OVA treatment (Fig. 3b). Interestingly, a significantly higher $\mathrm{R}_{\mathrm{N}}$ ) was already detected in PBS/OVA-treated $F / A 2^{\operatorname{tg} / \operatorname{tg}}$ mice challenged with $50 \mathrm{mg} / \mathrm{mL}$ of aerosolized methacholine when compared to PBS/OVA-treated $F / A 2^{w t / w t}$ mice (Fig. 3a). Both wild-type and transgenic mice showed significantly increased tissue elastance (H) (Fig. 3c, d) and resistance (G; Fig. 3e, f) when treated with the OVA/OVA protocol and challenged with methacholine. The increase of tissue elastance in response to methacholine was significantly higher in transgenic compared to wild-type mice (Fig. 3c, d), with the transgenic mice already showing an increased response to higher concentrations of methacholine on the PBS/OVA protocol. Transgenic mice were more sensitive

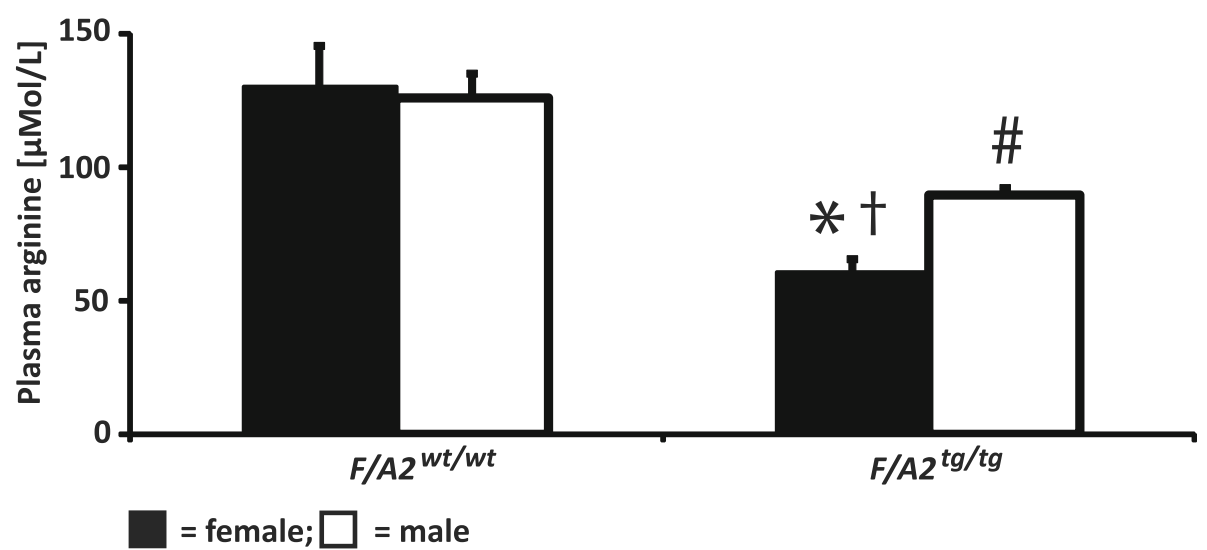

Fig. 1 Decline of plasma arginine concentrations in female and male $F / A 2^{\text {tg/tg }}$ mice. Black bars represent female and white bars male mice. Means \pm SEM of 7-8 mice per group. Significance symbols: ${ }^{*}=P<0.01 \mathrm{~F} / \mathrm{A} 2^{\text {tg/tg }}$ mice vs. F/A2 ${ }^{\text {wt/Wt }}$ (females); \# $=P<0.01 \mathrm{~F} / \mathrm{A} 2^{\text {tg/tg }}$ mice vs. F/A2 ${ }^{\text {wt } / w t}$ (males); $\dagger=P<0.05$ female vs. male $F / A 2^{\text {tg/tg }}$ mice 

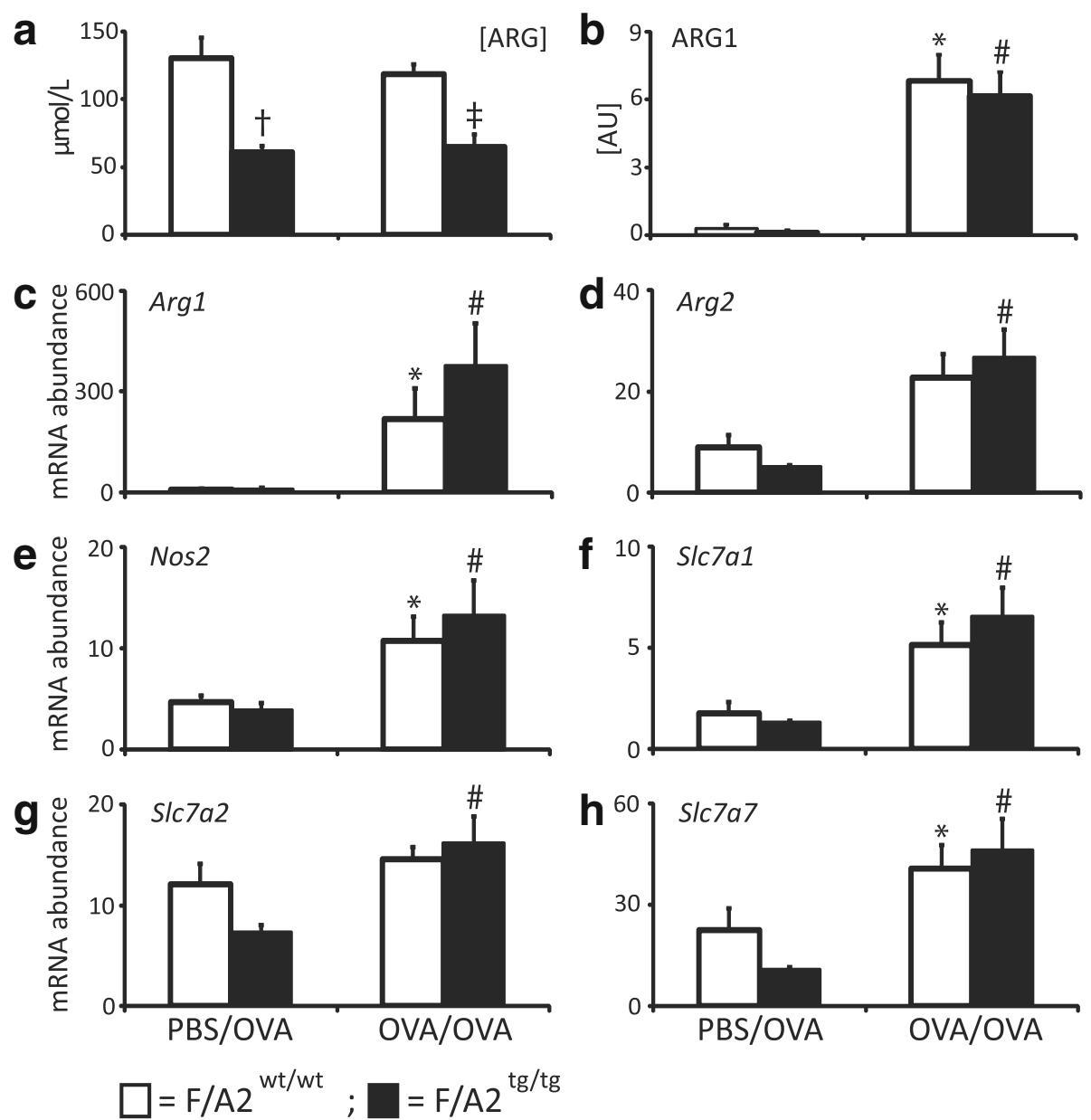

Fig. 2 Similar induction of arginine-metabolizing enzymes and arginine transporters in asthmatic hypoargininemic and control mice. Mice were subjected to either the PBS/OVA (control) or the OVA/OVA treatment protocol as indicated at the bottom. Panel a: plasma arginine concentration; Panel $\mathbf{b}$ : arginase 1 protein concentration in lung tissue as determined by Western blot. Panels c-e: mRNA abundance of the arginine-metabolizing enzymes Arg1, Arg2, and Nos2, respectively. Panels $\mathbf{f}-\mathbf{h}$ : mRNA abundance of the arginine transporters S/c7a1, S/c7a2 and S/C7a7. White bars represent data from F/A2 ${ }^{\text {wt } / \text { wt }}$ and black bars from F/A2t/tg mice. The Y-axis shows the number of mRNA copies after normalization to $18 \mathrm{~S}$ rRNA expression and multiplication by 10,000. Means \pm SEM of 9-10 mice per group. ${ }^{*}=P<0.05$ PBS/OVA vs. OVA/OVA $F / A 2^{w t / w t} ; \dagger=P<0.05$ PBS/OVA F/A2 ${ }^{\text {tg/tg }}$ vs. F/A2 $2^{\text {wt } / w t} ; \#=P<0.05$ PBS/OVA vs. OVA/OVA F/A2 ${ }^{\text {tg/tg }} ; \neq: P<0.05$ OVA/OVA F/A2 ${ }^{\text {tg/tg }}$ vs. F/A2 ${ }^{\text {wt } / w t}$

to methacholine in terms of tissue resistance $(P=0.0004$ at $3.1 \mathrm{mg} / \mathrm{mL}$ methacholine; $P=0.0001$ at $12.5 \mathrm{mg} / \mathrm{ml}$ methacholine) under the OVA/OVA protocol. Tissue resistance did not differ between genotypes under control conditions (PBS/OVA). In aggregate, these data show that hypoargininemia increased all aspects of airway responsiveness measured with the flexiVent ${ }^{\mathrm{m}}$ in mice with allergic asthma.

Hypoargininemia does not affect induction of inflammatory genes in allergically inflamed lungs

We next investigated whether hypoargininemia affected the gene expression of asthma-associated cytokines (Fig. 4). Allergen sensitization and challenge (OVA/ OVA) resulted in an increase in the abundance of $\mathrm{Il4}$, Il5, Il13, Ccl2, Ccl11, and Il10 mRNAs in both $F / A 2^{t g / t g}$ and $F / A 2^{w t / w t}$ mice. Furthermore, the expression of the respiratory epithelium-specific $M u c 5 a c$ and Clca3 genes was significantly increased, whereas the expression of Tnfa and Ifng remained unchanged. Clca3 mRNA expression was significantly increased in OVA/OVA-treated $F / A 2^{t g / t g}$ compared to their wild-type counter parts.

Hypoargininemia does not affect pulmonary levels of cytokines in allergically inflamed lungs

To investigate whether hypoargininemia had an effect on the protein concentration of pulmonary cytokines that are involved in allergic airway inflammation, we performed ELISAs for IL-4, IL-10, and IL-13 in protein extracts of whole-lung homogenates (Fig. 5). Both IL-4 (trend $p=0.057$ ) and IL-13 were induced by the OVA/OVA 

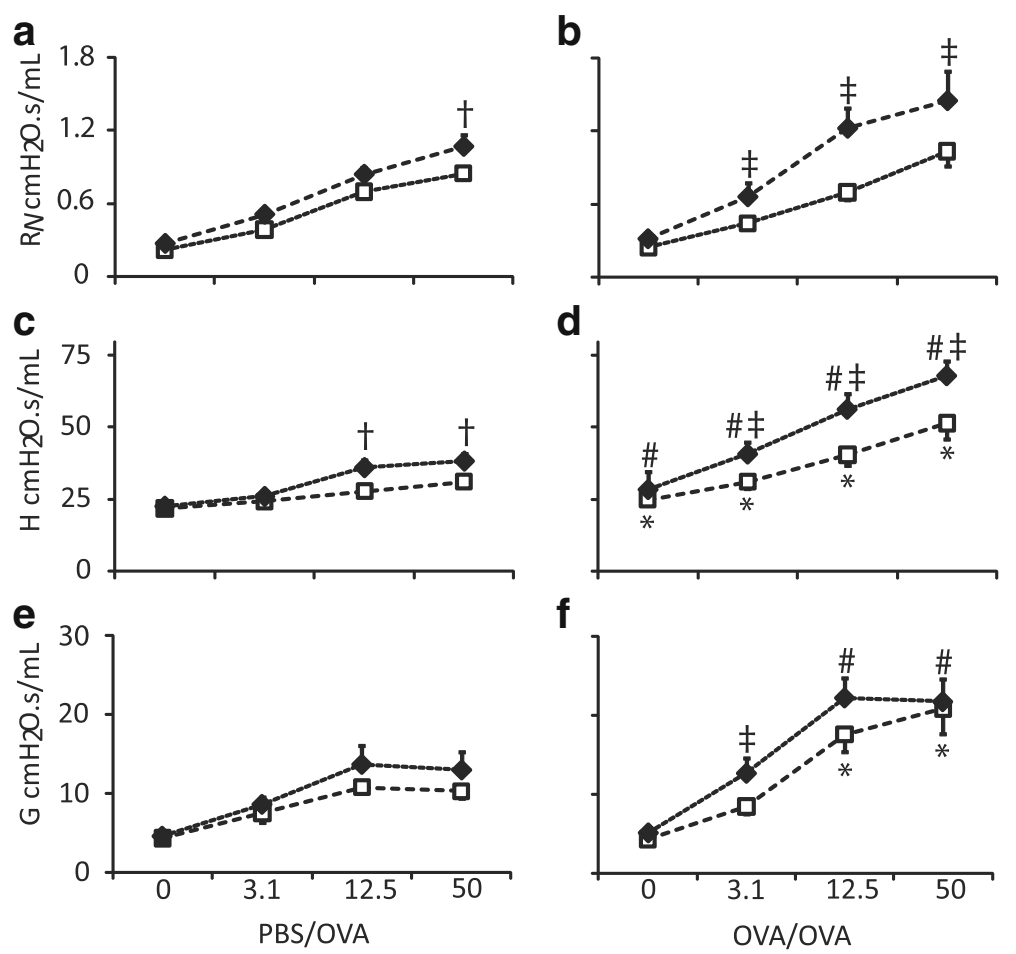

$$
-\square-=F / A 2^{w t / w t} ;-=F / A 2^{\text {tg/tg }}
$$

Fig. 3 Hypoargininemia aggravates lung dysfunction in asthmatic mice. Panels a, $\mathbf{c}$, and E show data from F/A2 ${ }^{\text {wt }}$ wt (white squares, continuous lines) and F/A2 ${ }^{\text {tg/tg }}$ mice (black diamonds, dashed lines), mock-sensitized with PBS and challenged with ovalbumin (OVA). Panels $\mathbf{b}$, d, and $\mathbf{f}$ show data from F/A2 $2^{\text {wt } / \text { t }}$ and $F / A 2^{\text {tg/tg }}$ mice that were sensitized and challenged with OVA. The treatment of the mice (PBS/OVA or OVA/OVA) is indicated below the columns. Top row: airway resistance $\mathrm{R}_{\mathrm{N}}$; middle row: tissue elastance $\mathrm{H}$; bottom row: tissue resistance $\mathrm{G}$. Values on the $\mathrm{X}$-axis represent the methacholine concentration used $[\mathrm{mg} / \mathrm{mL}]$. Means \pm SEM of $9-10$ mice per group. Significance symbols: *: $P<0.05$ PBS/OVA vs. OVA/OVA F/A2 $2^{w t / w t} ;$ †: $P<0.05$ PBS/OVA F/A2 $2^{\text {tg/tg }}$ vs. F/A2 $2^{w t / w t} ; \#: P<0.05$ PBS/OVA vs. OVA/OVA F/A2 $2^{\text {tg/tg }} ; \neq: P<0.05$ OVA/OVA F/A $2^{\text {tg/tg }}$ vs. F/A2 $2^{w t / w t}$

treatment to a similar extent in $F / A 2^{\operatorname{tg} / \operatorname{tg}}$ and $F / A 2^{w t / w t}$ mice, whereas IL-10 was not affected by the OVA/OVA treatment in both groups. OVA-specific IgE production was increased to a similar extent upon OVA/OVA treatment in both $F / A 2^{\operatorname{tg} / \operatorname{tg}}$ and $F / A 2^{w t / w t}$ mice.

\section{Hypoargininemia does not affect tissue inflammation in allergically inflamed lungs}

We investigated whether hypoargininemia modified the allergic asthma-induced inflammatory response in lung tissue (Fig. 6). H\&E-stained sections revealed no inflammatory cells in the lungs of PBS/OVA-treated mice (Fig. 6a). This finding was confirmed by staining sections of the same lungs for the presence of major basic protein (mMBP) and myeloperoxidase (MPO), eosinophil and neutrophil markers, respectively. As expected, inflammatory cells were abundant in the lungs of OVA/OVA-treated mice, but there was no difference between $F / A 2^{t g / t g}$ and $F / A 2^{w t / w t}$ mice. Semi-quantitative scoring of the sections for inflammatory cell density in the peribronchiolar, parenchymal and perivenous areas did not reveal differences between OVA/OVA-treated $F / A 2^{\operatorname{tg} / \operatorname{tg}}$ mice and their wild-type littermates (Fig. 6b).

\section{Hypoargininemia disturbs the coordinated response to asthma}

To answer the question whether circulating L-arginine concentrations changed the overall adaptive response to asthma, we determined the correlation coefficients between AHR parameters, mRNA and protein levels, histology scores and L-arginine concentrations in $F / A 2^{t g / t g}$ mice and their $F / A 2^{w t / w t}$ littermates (Fig. 7). The presence of 3 major blocs (lung function, mRNA expression, and lung histology) with high correlations between parameters in the response to OVA/OVA within a bloc and fewer significant correlations between the blocs is striking. mRNA concentrations in particular hardly correlated with function or histology. Furthermore, more significant correlations were seen in $F / A 2^{w t / w t}$ (wild-type FVB mice) than in $F / A 2^{t g / t g}$ mice, suggesting that arginine availability played a role in these responses. In more detail, we observed that significant correlations between the responses of lung function or lung histology 


\section{a}
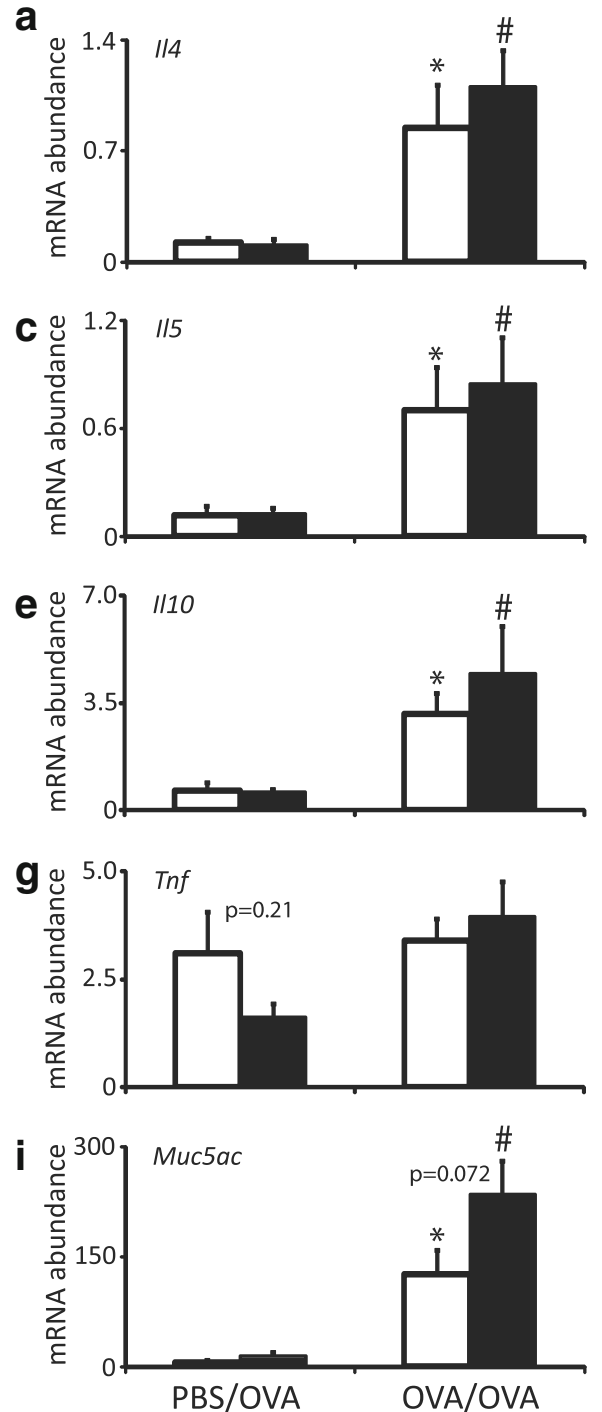

PBS/OVA

OVA/OVA

\section{b}

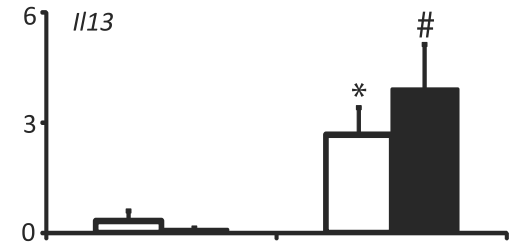

d
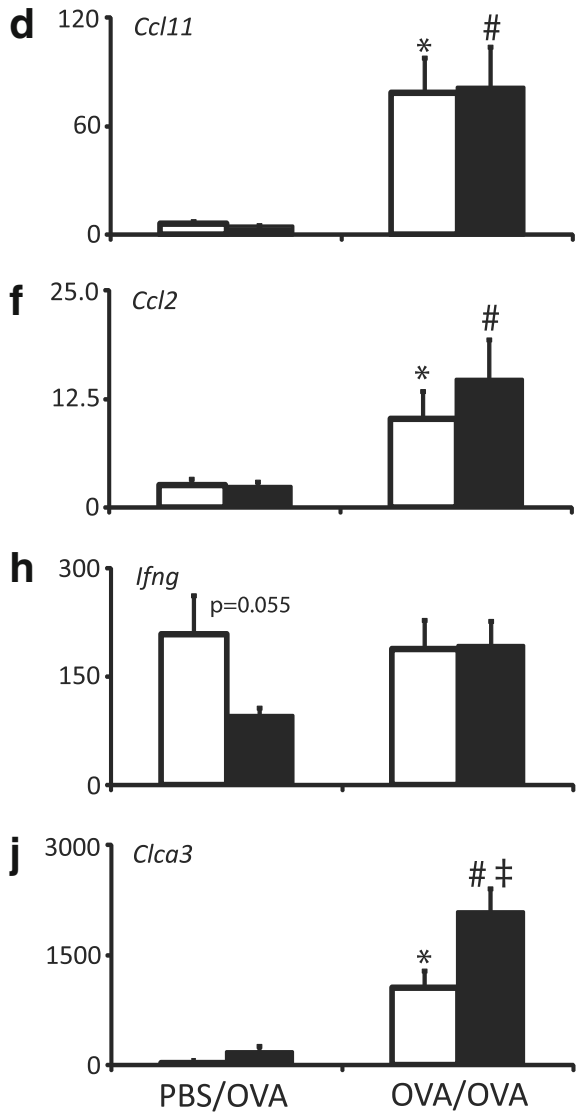

Fig. 4 Similar induction of inflammatory genes in asthmatic hypoargininemic and control mice. Data from F/A2 $2^{\text {wt/wt }}$ (white bars) and F/A2 $2^{\text {tg/tg }}$
(black bars) mice are shown. Mice were either mock-sensitized with PBS before the ovalbumin (OVA) challenge (PBS/OVA), or sensitized and (black bars) mice are shown. Mice were either mock-sensitized with PBS before the ovalbumin (OVA) challenge (PBS/OVA), or sensitized and
challenged with OVA (OVA/OVA) as indicated below panels I and J. Panels a-d: mRNA abundance of the $T_{H} 2$-related genes $/ 14,1113$, 115 and $C(111$, respectively. Panels e and $\mathbf{f}$ : mRNA abundance of anti-inflammatory gene $/ 110$ and macrophage-chemotactic gene $C(12$. Panels $\mathbf{g}$ and $\mathbf{h}$ : mRNA abundance of the $T_{H}$ 1-related genes Tnfa and Ifng. Panels $\mathbf{i}$ and $\mathbf{j}$ : mRNA abundance of marker genes for activation of bronchiolar epithelium Muc5ac and Clca3. The Y-axis shows the number of mRNA copies after normalization to 18S rRNA expression and multiplication by 10,000. Means \pm SEM of 7-8 mice per group. Significance symbols: *: $P<0.05$ PBS/OVA vs. OVA/OVA F/A2 ${ }^{\text {wt } / w t ;}$ \#: $P<0.05$ PBS/OVA vs. OVA/OVA F/A2 ${ }^{\text {tg/tg; }}$ \#: $P<0.05$ OVA/OVA F/A2 ${ }^{\text {tg/tg }}$ vs. F/A2 $2^{\text {wt } / \text { t }}$

parameters to OVA/OVA treatment were more frequently seen in $F / A 2^{w t / w t}$ than in $F / A 2^{t g / t g}$ mice. In contrast, the responses in mRNA expression to OVA/OVA treatment were similar in both types of mice, with the notable exception of the expression of Il10 (no correlation with other mRNAs in $F / A 2^{t g / t g}$ ) and Tnf and Ifng (stronger correlations). Plasma arginine concentrations correlated inversely with large airway resistance. In aggregate, these data show that hypoargininemia disturbed the coordinated asthma response. The finding that tissue inflammation did not correlate well with lung function parameters in $F / A 2^{t g / t g}$ mice indicates that these events do not share a common regulatory path in this mouse model of asthma [25]. 

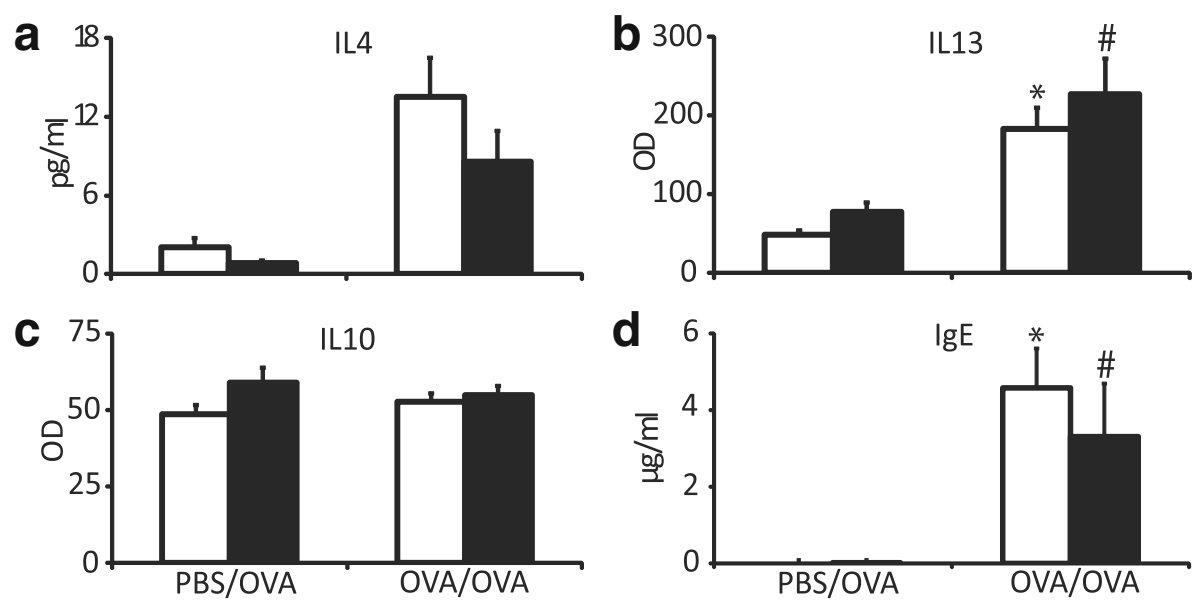

$$
\square=F / A 2^{w t / w t} ; \square=F / A 2^{\operatorname{tg} / \mathrm{tg}}
$$

Fig. 5 Similar changes in pulmonary content of inflammatory cytokines and OVA-specific lgE in asthmatic hypoargininemic and control mice. F/A2 ${ }^{\text {wt }}$ wt (white bars) and F/A2 ${ }^{\text {tg/tg }}$ mice (black bars) were either mock-sensitized with PBS and challenged with ovalbumin (OVA; PBS/OVA), or sensitized and challenged with OVA (OVA/OVA) as indicated below the graphs. Cytokine or IgE concentrations were determined in lung tissue powder. Panel a-d: concentrations of IL4, IL13, IL10, and IgE, respectively, in plasma. The concentrations of IL13 and IL10 are expressed in arbitrary units. Means \pm SEM of 7-8 mice per group. Significance symbols: ${ }^{*}: P<0.05$ PBS/OVA vs. OVA/OVA F/A2 ${ }^{\text {wt } w t}$; \#: $P<0.05$ PBS/OVA vs. OVA/OVA F/A2 ${ }^{\text {tg/tg }}$

\section{Discussion}

In this study, we investigated the symptoms of allergic asthma in hypoargininemic $F / A 2^{\text {tg/tg }}$ mice [19]. The decrease of the circulating arginine concentration as a result of arginase 1 overexpression in the enterocytes was most profound in female mice. OVA/OVA treatment did not change the plasma arginine concentration in either $F / A 2^{t g / t g}$ or $F / A 2^{w t / w t}$ mice, nor did it affect sensitization to OVA, as demonstrated by similar increases of OVA-specific IgE in both genotypes. Airway resistance and tissue elastance were markedly increased in OVA/OVA-treated $F / A 2^{\text {tg/tg }}$ mice compared to similarly treated $F / A 2^{w t / w t}$ mice, while tissue resistance in $F / A 2^{t g / t g}$ mice was more sensitive to methacholine than that of similarly treated $F / A 2^{w t / w t}$ mice. Remarkably, the increased airway resistance and tissue elastance were already evident in PBS/OVA-treated $F / A 2^{t g / t g}$ mice at high concentrations of methacholine. The abundance of arginine-transporting and -metabolizing mRNAs and that of inflammatory markers increased to an equal extent in both genotypes after OVA/OVA treatment. The only observed difference was a larger increase in mRNA abundance of $\mathrm{Clca} 3$ and $M u c 5 a c$ (trend, $p=0.072$ ) in F/A2 $2^{t g / t g}$ mice. Clca3 and Muc5ac are involved in mucus production and expressed by lung goblet cells. The findings show that the circulating concentration of arginine has a pronounced effect of airway biomechanics, but not on inflammation.

\section{Overexpression of arginase 1 causes hypoargininemia}

In adult mice, overexpression of arginase 1 in enterocytes makes these cells an efficient arginine sink. Compared to $F / A 2^{w t / w t}$ mice, arginine concentration in plasma of $F / A 2^{\operatorname{tg} / \mathrm{tg}}$ mice dropped by $\sim 25 \%$ (from $126 \mu \mathrm{mol} / \mathrm{mL}$ to $90 \mu \mathrm{mol} / \mathrm{mL}$ ), and $\sim 50 \%$ (from $124 \mu \mathrm{mol} / \mathrm{mL}$ to $63 \mu \mathrm{mol} / \mathrm{mL})$ in male and female $F / A 2^{t g / t g}$ mice, respectively. Please note that we reported earlier that males were more affected than females [26], but that subsequent studies, including the present (Fig. 1), revealed that this conclusion was due to mislabeled blood samples.

\section{Hypoargininemia does not alter the inflammatory response or the expression of arginine-metabolizing or -transporting enzymes in the lung}

Elimination of Arg1 expression in macrophages has been accomplished by bone-marrow transfer from 9 to 12-day old Arg1-deficient pups to congenic recipient mice [17] or by Tie2Cre-mediated deletion of floxed Arg1 alleles in hematopoietic tissues $[11,12,18]$. Allergic airway inflammation was induced by sensitizing such mice to ovalbumin, Aspergillus, or Schistosoma eggs. Furthermore, these tests were not only carried out in $\mathrm{T}_{\mathrm{H}} 1$-prone C57BL/6, but also in $\mathrm{T}_{\mathrm{H}} 2$-prone BALB/c mice. Despite this very broad approach, these studies found no effects of Arg1 deficiency in macrophages on allergic inflammatory responses or function tests of the lungs. The 


\section{a}
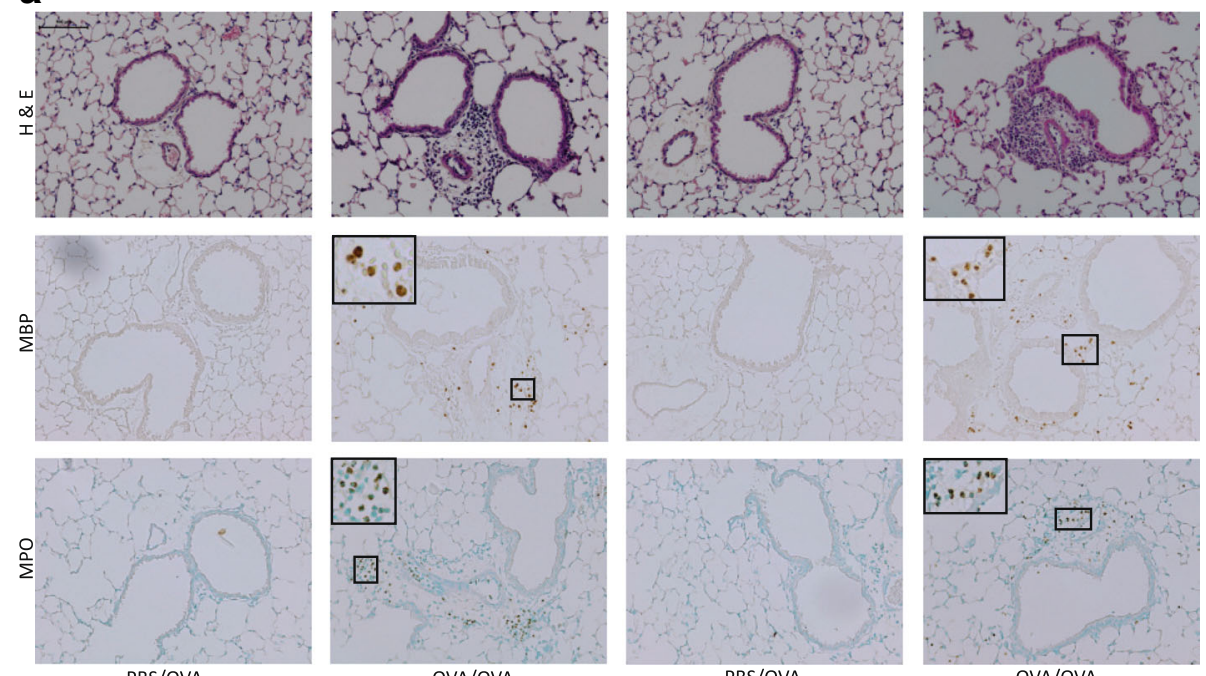

PBS/OVA

OVA/OVA

PBS/OVA

OVA/OVA

b

$\mathrm{F} / \mathrm{A} 2^{w t / w t}$

$\mathrm{F} / \mathrm{A} 2^{\mathrm{tg} / \mathrm{tg}}$
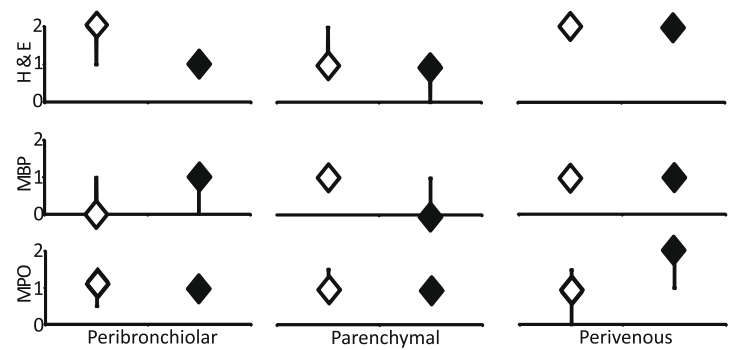

$\diamond=F / A 2^{w t / w t}$

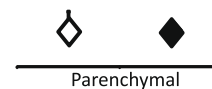

Perivenous

Fig. 6 Similar prevalence of inflammatory cells in the lungs of asthmatic hypoargininemic and control mice. F/A2 $2^{\text {wt } / w t}$ and F/A2 ${ }^{\text {tg/tg }}$ mice were either mock-sensitized with PBS and challenged with OVA (PBS/OVA) or sensitized and challenged with OVA (OVA/OVA) as indicated. Panel a, top row: H\&E-stained sections of the peribronchiolar region of the lung; middle row: mMBP-positive (eosinophilic) cells; bottom row: MPO-positive (neutrophilic) cells. Panel $\mathbf{S}$ : quantification in the sections of inflammatory cells in OVA-OVA-treated F/A2 ${ }^{\text {wt } / \text { wt }}$ (white diamonds) and F/A2 ${ }^{\text {tg/tg }}$ mice (black diamonds). The sections that were compared were stained simultaneously. Inflammatory scores were analyzed per lung region, i.e. peribronchiolar, parenchymal and perivenous (around the lung veins), and scored on a scale from 0 to 3 by two independent observers. Medians and quartiles of 7-8 mice per group are shown (when not drawn, quartiles coincide with medians). No differences in inflammatory scores were found

present study reports that a $\sim 50 \%$ decrease in plasma arginine concentration also did not affect the expression of inflammation-associated genes or the histopathology in the lungs in response to OVA/OVA treatment, even though this low ambient arginine concentration causes a clear phenotype [19] due to the induction of the endoplasmic reticulum-stress response [27]. OVA/OVA treatment affected the expression of arginine-transporting and -metabolizing genes in Arg1-deficient mice [11, 12], but not in $F / A 2^{\operatorname{tg} / \operatorname{tg}}$ mice. This finding suggests that quantitively arginine metabolism in the lungs is largely confined to macrophages. In agreement, it was earlier reported that local arginine deficiency suppresses T-cell activation and thus limits the inflammatory response [28]. Interestingly, it was also reported that a high oral dose of L-arginine reduces airway inflammation, and $\mathrm{T}_{\mathrm{H}} 2$ cytokine and mucus production in a mouse model of asthma [29].

\section{Hypoargininemia does disrupt lung mechanics}

Absence of ARG1 from macrophages did not affect the ventilatory function of allergically inflamed lungs in the studies of Niese [17] and Barron [18]. Peripheral lung function was slightly better protected in Arg1-deficient OVA/OVA-treated male C57BL/6 mice than in their wild-type littermates [11], but this protective effect of Arg1 deficiency in macrophages was not found in female mice [12]. The present study shows that a $\sim 50 \%$ reduction of plasma arginine concentration increases airway resistance and tissue elastance, and the sensitivity of 


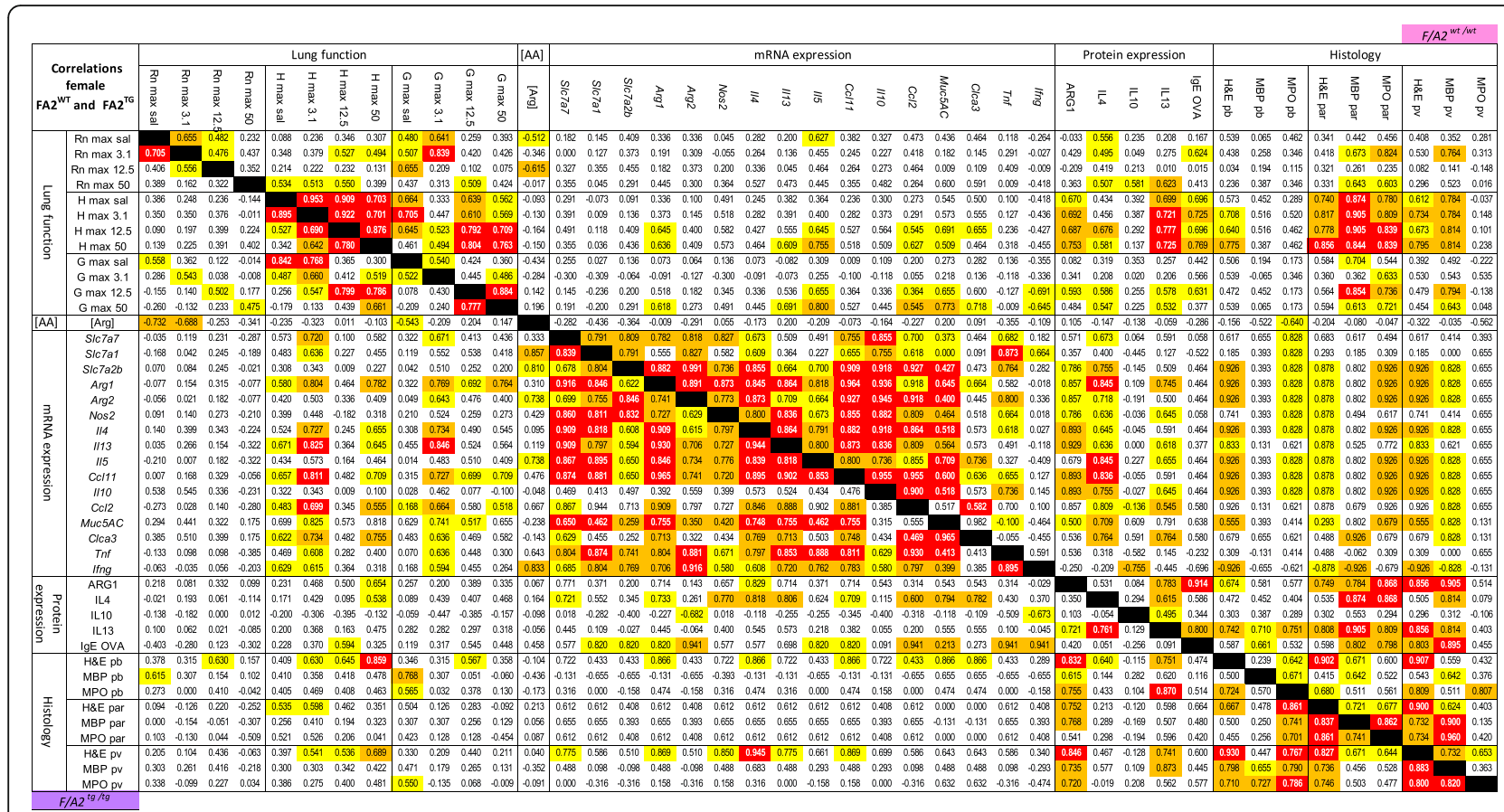

Fig. 7 Disruption of coordinated response to allergic asthma in hypoargininemic and control mice. The correlation of parameters of lung function, plasma concentration of arginine, abundance of pulmonary mRNAs and proteins, and pulmonary histopathology were compared in control and asthmatic $F / A 2^{t g} / t g$ and wild-type littermate mice. Correlation coefficients of parameters indicated above and to the left of the columns and rows, respectively, are shown for $F / A 2^{\text {wt } / w t}$ (upper right triangle) and $F / A 2^{\text {tg/tg }}$ mice (lower left triangle). $n=15$ or 16 PBS/OVA- and OVA/OVA-treated mice of both genotypes. The significance of the correlations is color-coded according to the $P$-value of the correlation coefficient (Spearman's rho): yellow: $0.05>P>0.01$, orange: $0.01>P>0.001$, and red: $P<0.001$

tissue resistance to methacholine treatment in OVA/ OVA-treated $F / A 2^{t g / t g}$ mice. Moreover, some of these effects were already seen in PBS/OVA-treated $F / A 2^{\text {tg/tg }}$ mice, albeit to a lesser extent. The pronounced effect of hypoargininemia on lung function is remarkable, because it apparently exerts its effect outside the macrophages. These macrophages accumulate in the peribronchiolar space of asthmatic lungs, that is, close to the smooth muscle cells of the airways (see Fig. 6) and express high levels of arginase [1]. The ambient concentration of arginine had a large effect on the contraction of perfused guinea-pig tracheal rings ex vivo [30] and a high oral dose of L-arginine reduced AHR in mice in vivo [29]. Apparently, the elimination of arginase 1 expression from the peribronchial macrophages does not result in a sufficiently high local increase in arginine concentration to reduce airway resistance or mucus production. The finding that a decrease in plasma arginine concentration does aggravate the symptoms of allergic asthma suggests that a limitation of systemic L-arginine availability impairs relaxation in airway smooth muscle cells.

One reason for the sensitivity of lung mechanics to circulating rather than local arginine concentration may be the very strong perfusion of the lung and, hence, buffering effect of plasma arginine. It seems reasonable to mechanistically ascribe the dependence of lung function on circulating arginine to arginine availability for NO production. Genetic elimination of the NOS2 enzyme has been demonstrated to aggravate AHR in OVA/OVA-treated mice and resulted in a $\sim 2$-fold reduction of the exhaled NO concentration $[8,10,31]$. NOS1-KO mice recruit fewer eosinophils $(\sim 70 \%$ of wild-type) and produce less NO ( 10\% of wild-type) in a mouse model of OVA-induced asthma, and upregulation of NOS2 is abolished [9]. NOS3-KO mice are inherently hyperresponsive to inhaled methacholine [7]. The demonstration that NOS2 produces peroxynitrite in allergic asthma [32] indicates that NOS2 already tends to produce superoxide rather than nitric oxide under this condition [16]. Superoxide production by NOS is a marker for cellular arginine or BH4 deficiency [33] and may well explain why a high oral dose of L-arginine reduced the production of markers of nitro-oxidative stress, such as nitrotyrosine [29]. In aggregate, the findings in Nos-deficient mice show that NO plays a prominent if not determining role in AHR and underscore our hypothesis that hypoargininemia aggravates AHR in severe allergic asthma via a decrease in NO production. These experimental findings confirm the earlier clinical 
observation that L-arginine availability is related to airflow obstruction in severe asthma [4].

\section{Limitations of the study}

The experimental model we used to base our conclusion on is a transgenic model. The disadvantage of transgenic models is that the life-long exposure to in this case hypoargininemia may have additional features that could affect the response to allergic asthma. The physiologically most attractive option to assess such a potential confounder would be to supplement $F / A 2^{\text {tg/tg }}$ mice with arginine. When we carried out this experiment by treating mice twice daily for 5 days with $5 \mathrm{mmol} / \mathrm{kg}$ arginine and measuring plasma arginine concentration $6 \mathrm{~h}$ after the last injection [26], circulating arginine concentration in wild-type mice increased $>2$-fold, but the intervention was without any effect in $F / A 2^{\operatorname{tg} / \operatorname{tg}}$ mice. Since circulating arginine concentrations vary directly with transgenic arginase activity in the small intestine of $F / A 2^{\operatorname{tg} / \operatorname{tg}}$ mice [19], the high turnover of plasma arginine in $F / A 2^{\operatorname{tg} / t g}$ mice apparently neutralizes the supplemented arginine. An alternative option would be to infuse arginase intravenously into wild-type mice. This intervention is very effective in lowering circulating arginine concentrations, but also short-lived [34], so that it could not be used in the present setting. A third approach could have been treatment of $F / A 2^{\text {tg/tg }}$ mice with a well-established arginase inhibitor such as nor-NOHA. However, nor-NOHA is an arginine analogue which requires $\sim 10$-fold higher concentration to inhibit intracellular than dissolved arginase [35], suggesting it has to compete with arginine-like molecules for membrane transport. Probably more seriously, its $K_{i}$ for mouse macrophage arginase is $50 \mu \mathrm{mol} / \mathrm{L}$, that is, similar to circulating arginine concentrations in $F / A 2^{\text {tg/tg }}$ mice. These considerations show that the $F / A 2^{\operatorname{tg} / \operatorname{tg}}$ mouse model was instrumental in revealing a potential requirement for circulating arginine in severe allergic asthma, but that additional studies are necessary to reaffirm this function.

\section{Conclusion}

Reduction of circulating arginine levels by $\sim 50 \%$ in a mouse model of OVA-induced asthma leads to an increase in AHR as shown by the increases in $R_{N}, H$, and $\mathrm{G}$, without altering the inflammatory response or the expression of arginine-metabolizing or transporting enzymes in the lung. Ablation of arginase 1 in macrophages, on the other hand did not result in an improvement of any of the lung function parameters. We conclude that the reduction of circulating $\mathrm{L}$-arginine levels rather than a macrophage-mediated increase in arginine catabolism worsens AHR.

\section{Additional files}

Additional file 1: Figure S1. Arg1, Nos2, and Cd68 expression in lungs of OVA-sensitized FVB mice before (Control, $n=4)$ and after $1(n=12)$ or 6 $(n=12)$ challenges with aerosolized OVA. (PDF $374 \mathrm{~kb})$

Additional file 2: Tables S1. Primer pairs used for genotyping and quantitative PCR. Table S2. Amino-acid concentrations in venous plasma $(\mu \mathrm{M} \pm \mathrm{SEM})$ of $F / A 2^{w t / w t}$ and $F / A 2^{t g / t g}$ female mice. (DOCX $21 \mathrm{~kb}$ )

\section{Abbreviations}

(m)MBP: (murine) major basic protein; AHR: Airway hyperresponsiveness; Arg: Arginase; CAT: Cationic amino acid transporter; Ccl11: C-C motif chemokine ligand 11; Ccl2: C-C motif chemokine ligand 2; Clca3: Calciumactivation chloride channel family member 3; F/A2: transgenic mice on a FVB background that overexpress rat arginase 1 in their enterocytes; $\mathrm{G}$ : tissue resistance; $\mathrm{H}$ : tissue elastance; Ifng: interferon gamma; II: interleukin; LAT: heterodimeric amino acid transporter; MPO: myeloperoxidase; NO: nitric oxide; NOS: nitric oxide synthetase; OVA: ovalbumin; PBS: phosphate-buffered saline; $R_{N}$ : airway resistance; RT: room temperature; Slc7a1/2/7: solute carrier family 7 members 1, 2 or 7 resp.; Tnfa: tumor necrosis factor alpha; Zrs - input impedance

\section{Funding}

This study was supported by a grant from the Transnational University Limburg.

\section{Availability of data and materials}

All data generated or analyzed during this study are included in this published article (and its Additional files 1 and 2).

\section{Authors' contributions}

RHEC performed the experiments, made substantial contributions to the analysis and interpretation of data and wrote the initial draft of the manuscript; MEP participated in the acquisition of data and the revision of the manuscript; ET participated in the acquisition of data and provided technical support; WHL and SEK conceived of the study and contributed substantially to the interpretation of data and the revision of the manuscript. All authors read and approved the final manuscript.

\section{Ethics approval}

All animal experiments were reviewed and approved by the committee for animal care and use of Maastricht University (DEC2005-146).

\section{Competing interests}

The authors declare that they have no competing interests.

\section{Publisher's Note}

Springer Nature remains neutral with regard to jurisdictional claims in published maps and institutional affiliations.

\section{Author details}

'Department of Anatomy \& Embryology and NUTRIM School of Nutrition and Translational Research in Metabolism, Maastricht University, P.O. Box 616, 6200MD, Maastricht, The Netherlands. ${ }^{2}$ Tytgat Institute for Liver and Intestinal Research, Academic Medical Center, Amsterdam, The Netherlands.

${ }^{3}$ Department of Medicine, College of Medicine, Division of Pulmonary Disease and Critical Care, University of Vermont, VT, Burlington, USA.

Received: 31 December 2017 Accepted: 10 May 2018

Published online: 23 May 2018

\section{References}

1. Zimmermann N, Rothenberg ME. The arginine-arginase balance in asthma and lung inflammation. Eur J Pharmacol. 2006;533:253-62.

2. North ML, Khanna N, Marsden PA, Grasemann H, Scott JA. Functionally important role for arginase 1 in the airway hyperresponsiveness of asthma. Am J Physiol Lung Cell Mol Physiol. 2009;296:L911-20.

3. Ricciardolo FL. Multiple roles of nitric oxide in the airways. Thorax. 2003;58:175-82. 
4. Lara A, Khatri SB, Wang Z, Comhair SA, Xu W, Dweik RA, Bodine M, Levison BS, Hammel J, Bleecker $\mathrm{E}$, et al. Alterations of the arginine metabolome in asthma. Am J Respir Crit Care Med. 2008;178:673-81.

5. Hammermann R, Hirschmann J, Hey C, Mossner J, Folkerts G, Nijkamp FP, Wessler I, Racke K. Cationic proteins inhibit L-arginine uptake in rat alveolar macrophages and tracheal epithelial cells. Implications for nitric oxide synthesis. Am J Respir Cell Mol Biol. 1999;21:155-62.

6. De Sanctis GT, MacLean JA, Hamada K, Mehta S, Scott JA, Jiao A, Yandava CN, Kobzik L, Wolyniec WW, Fabian AJ, et al. Contribution of nitric oxide synthases 1, 2, and 3 to airway hyperresponsiveness and inflammation in a murine model of asthma. J Exp Med. 1999;189:1621-30.

7. Feletou M, Lonchampt M, Coge F, Galizzi JP, Bassoullet C, Merial C, Robineau P, Boutin JA, Huang PL, Vanhoutte PM, Canet E. Regulation of murine airway responsiveness by endothelial nitric oxide synthase. Am J Physiol Lung Cell Mol Physiol. 2001;281:L258-67.

8. Cook S, Vollenweider P, Menard B, Egli M, Nicod P, Scherrer U. Increased eNO and pulmonary iNOS expression in eNOS null mice. Eur Respir J. 2003;21:770-3.

9. lijima H, Tulic MK, Duguet A, Shan J, Carbonara P, Hamid Q, Eidelman DH. NOS 1 is required for allergen-induced expression of NOS 2 in mice. Int Arch Allergy Immunol. 2005;138:40-50.

10. Bratt JM, Franzi LM, Linderholm AL, Last MS, Kenyon NJ, Last JA. Arginase enzymes in isolated airways from normal and nitric oxide synthase 2-knockout mice exposed to ovalbumin. Toxicol Appl Pharmacol. 2009;234:273-80.

11. Cloots RH, Sankaranarayanan S, de Theije CC, Poynter ME, Terwindt E, van Dijk P, Hakvoort TB, Lamers WH, Kohler SE. Ablation of Arg1 in hematopoietic cells improves respiratory function of lung parenchyma, but not that of larger airways or inflammation in asthmatic mice. Am J Physiol Lung Cell Mol Physiol. 2013;305:L364-76.

12. Cloots RHE, Sankaranarayanan S, Poynter ME, Terwindt E, van Dijk P, Lamers WH, Eleonore Kohler S. Arginase 1 deletion in myeloid cells affects the inflammatory response in allergic asthma, but not lung mechanics, in female mice. BMC Pulm Med. 2017;17:158.

13. Zimmermann N, King NE, Laporte J, Yang M, Mishra A, Pope SM, Muntel EE, Witte DP, Pegg AA, Foster PS, et al. Dissection of experimental asthma with DNA microarray analysis identifies arginase in asthma pathogenesis. J Clin Invest. 2003;111:1863-74

14. Kenyon NJ, Bratt JM, Linderholm AL, Last MS, Last JA. Arginases I and II in lungs of ovalbumin-sensitized mice exposed to ovalbumin: sources and consequences. Toxicol Appl Pharmacol. 2008;230:269-75.

15. Wu G, Morris SM Jr. Arginine metabolism: nitric oxide and beyond. Biochem J. 1998;336(Pt 1):1-17.

16. Xia Y, Roman LJ, Masters BS, Zweier JL. Inducible nitric-oxide synthase generates superoxide from the reductase domain. J Biol Chem. 1998;273:22635-9.

17. Niese KA, Collier AR, Hajek AR, Cederbaum SD, O'Brien WE, Wills-Karp M, Rothenberg ME, Zimmermann N. Bone marrow cell derived arginase I is the major source of allergen-induced lung arginase but is not required for airway hyperresponsiveness, remodeling and lung inflammatory responses in mice. BMC Immunol. 2009;10:33.

18. Barron L, Smith AM, El Kasmi KC, Qualls JE, Huang X, Cheever A, Borthwick LA, Wilson MS, Murray PJ, Wynn TA. Role of arginase 1 from myeloid cells in th2-dominated lung inflammation. PLoS One. 2013;8:e61961.

19. de Jonge WJ, Hallemeesch MM, Kwikkers KL, Ruijter JM, de Gier-de Vries C, van Roon MA, Meijer AJ, Marescau B, de Deyn PP, Deutz NE, Lamers WH. Overexpression of arginase I in enterocytes of transgenic mice elicits a selective arginine deficiency and affects skin, muscle, and lymphoid development. Am J Clin Nutr. 2002;76:128-40.

20. Hantos Z, Daroczy B, Suki B, Nagy S. Low-frequency respiratory mechanical impedance in the rat. J Appl Physiol. 1987;63:36-43.

21. Fredberg JJ, Stamenovic D. On the imperfect elasticity of lung tissue. J Appl Physiol. 1989;67:2408-19.

22. van Eijk HM, Rooyakkers DR, Deutz NE. Rapid routine determination of amino acids in plasma by high-performance liquid chromatography with a 2-3 microns Spherisorb ODS II column. J Chromatogr. 1993;620:143-8.

23. Lee JJ, Dimina D, Macias MP, Ochkur SI, McGarry MP, O'Neill KR, Protheroe C, Pero R, Nguyen T, Cormier SA, et al. Defining a link with asthma in mice congenitally deficient in eosinophils. Science. 2004;305:1773-6.

24. Ruijter JM, Ramakers C, Hoogaars WM, Karlen Y, Bakker O, van den Hoff MJ, Moorman AF. Amplification efficiency: linking baseline and bias in the analysis of quantitative PCR data. Nucleic Acids Res. 2009;37:e45.
25. Poynter ME, Cloots R, van Woerkom T, Butnor KJ, Vacek P, Taatjes DJ, Irvin CG, Janssen-Heininger YM, NF-kappa B. Activation in airways modulates allergic inflammation but not hyperresponsiveness. J Immunol. 2004:173:7003-9.

26. de Jonge WJ, Marescau B, D'Hooge R, De Deyn PP, Hallemeesch MM, Deutz NE, Ruijter JM, Lamers WH. Overexpression of arginase alters circulating and tissue amino acids and guanidino compounds and affects neuromotor behavior in mice. J Nutr. 2001;131:2732-40.

27. Marion V, Sankaranarayanan S, de Theije C, van Dijk P, Lindsey P, Lamers MC, Harding HP, Ron D, Lamers WH, Kohler SE. Arginine deficiency causes runting in the suckling period by selectively activating the stress kinase GCN2. J Biol Chem. 2011;286:8866-74

28. Pesce JT, Ramalingam TR, Mentink-Kane MM, Wilson MS, El Kasmi KC, Smith AM, Thompson RW, Cheever AW, Murray PJ, Wynn TA. Arginase-1expressing macrophages suppress Th2 cytokine-driven inflammation and fibrosis. PLoS Pathog. 2009;5:e1000371.

29. Mabalirajan U, Ahmad T, Leishangthem GD, Joseph DA, Dinda AK, Agrawal A, Ghosh B. Beneficial effects of high dose of L-arginine on airway hyperresponsiveness and airway inflammation in a murine model of asthma. J Allergy Clin Immunol. 2010;125:626-35.

30. Maarsingh $\mathrm{H}$, Bossenga BE, Bos IS, Volders HH, Zaagsma J, Meurs H. Larginine deficiency causes airway hyperresponsiveness after the late asthmatic reaction. Eur Respir J. 2009;34:191-9.

31. Kenyon NJ, Gohil K, Last JA. Susceptibility to ovalbumin-induced airway inflammation and fibrosis in inducible nitric oxide synthetase-deficient mice: mechanisms and consequences. Toxicol Appl Pharmacol. 2003:191:2-11.

32. de Boer J, Meurs H, Flendrig L, Koopal M, Zaagsma J. Role of nitric oxide and superoxide in allergen-induced airway hyperreactivity after the late asthmatic reaction in Guinea-pigs. Br J Pharmacol. 2001;133:1235-42.

33. Luo S, Lei H, Qin H, Xia Y. Molecular mechanisms of endothelial NO synthase uncoupling. Curr Pharm Des. 2014;20:3548-53.

34. Chennupati R, Meens MJ, Marion V, Janssen BJ, Lamers WH, De Mey JG, Kohler SE. Endothelial arginine resynthesis contributes to the maintenance of vasomotor function in male diabetic mice. PLoS One. 2014;9:e102264.

35. Pudlo M, Demougeot C, Girard-Thernier C. Arginase inhibitors: a rational approach over one century. Med Res Rev. 2017;37:475-513.

\section{Ready to submit your research? Choose BMC and benefit from:}

- fast, convenient online submission

- thorough peer review by experienced researchers in your field

- rapid publication on acceptance

- support for research data, including large and complex data types

- gold Open Access which fosters wider collaboration and increased citations

- maximum visibility for your research: over $100 \mathrm{M}$ website views per year

At BMC, research is always in progress.

Learn more biomedcentral.com/submissions 